\title{
Pengaruh Partisipasi Masyarakat Dan Kebijakan Pemerintah Terhadap Pengurangan Penyebaran Virus Covid 19
}

\author{
${ }^{1}$ Andi Heru Susanto, ${ }^{2}$ Budi S. Kramadibrata \\ ${ }^{1,2}$ Program Studi Manajemen, STIE Media Nusantara Citra \\ andi.heru@stiemnc.ac.id budi.kramadibrata@stiemnc.ac.id
}

\begin{abstract}
Abstrak: Pemutus mata rantai penyebaran virus covid 19 menjadi tanggung jawab kita semua, bukan hanya pemerintah pelaksana medis tetapi juga perlu dukungan dari masyarakat melalui partisipasi. Partisipasi merupakah hal yang harus dilakukan oleh semua lapisan masyarakat Indonesia guna pengurangan penyebaran virus ini. Penelitian ini dimaksudkan untuk mengetahui pengaruh partisipasi masyarakat dan kebijakan pemerintah untuk mengurangi penyebaran virus covid 19 dengan menggunakan metode kuantitatif serta analisis structural equation model (SEM). Jumlah populasi sebanyak 150 orang dengan metode metadata non probability sampling serta melakukan observasi selama 60 hari ( 2 bulan). Hasil penelitian ini menunjukkan bahwa dengan Partisipasi Masyarakat yang tinggi dan pengambilan Kebijakan Pemerintah yang tepat dapat mengurangi penyebaran virus covid 19 di Indonesia.
\end{abstract}

Kata Kunci: Partisipasi Masyarakat; Kebijakan Pemerintah; Virus Covid 19

Abstract: Breaking the chain of covid 19 virus is the responsibility of all of us, not only the government, medical workers, but also it needs support from the community through participation. Participation is something that must be done by all levels of Indonesian society in order to reduce the spread of this virus. This study is intended to determine the effect of community participation and government policy to reduce the spread of the covid 19 virus by using quantitative methods and structural equation model analysis (SEM). Total population of 150 people with non-probability sampling metadata method and observing for 60 days $(2$ months). The results of this study indicate that with high Community Participation and appropriate Government Policy making can reduce the spread of the covid 19 virus in Indonesia.

Keywords: Community Participation; Government Policy; Covid 19 Virus.

\section{PENDAHULUAN}

Coronavirus Disease 2019 atau COVID19 merupakan penyakit baru yang dapat menyebabkan gangguan pernapasan dan radang paru. Penyakit ini disebabkan oleh infeksi Severe Acute Respiratory Syndrome Coronavirus 2 (SARS-CoV-2). Gejala klinis yang muncul beragam, mulai dari seperti gejala flu biasa (batuk, pilek, nyeri tenggorok, nyeri otot, nyeri kepala) sampai yang berkomplikasi berat. (DKI Jakarta, 2020). Virus Covid 19 pertama kali ditemuakan di Wuhan, China pada akhir 2019 tahun lalu. Sudah hampir 200 negara di dunia melaporkan adanya kasus terpapar virus covid ini. Indonesia sendiri pertama kali masyarakat yang terjangkit virus covid 19 adalah dua warga Depok pada awal Maret 2020 yang lalu.
Data hingga Jumat, 1 Mei 2020 secara nasional virus covid 19 di Indonesia telah mencapai 10.551 kasus positif terdiri atas $8.160(77 \%)$ dirawat, 1,591 (15\%) sembuh dan $800(8 \%)$ meninggal. Sedangkan untuk DKI Jakarta sebagai salah satu kota yang termasuk dalam katagori kota zona merah kasus positip hingga Jumat 1 Mei 2020 sebanyak 4.283 kasus terdiri atas $2.151(50 \%)$ dirawat, $427(10 \%)$ sembuh, 393 (9\%) meninggal dan 1.312 (31\%) isolasi mandiri. (DKI Jakarta, 2020). Secara nasional penambahan kasus baru perhari terhitung Jumat 1 Mei 2020 sebanyak 433 kasus dangan penambahan tingkat kematian di tanggal yang sama sebanyak 8 orang. (Indonesia, 2020). Sedangkan untuk DKI Jakarta penambahan kasus positif perhari terhitung hingga Jumat 1 Mei 2020 sebanyak 145 kasus dan kondisi 
meninggal sebanyak 12 orang (DKI Jakarta, 2020).

Berbeda dengan Indonesia, Vietnam merupakan salah satu negara yang berhasil memutus mata rantai penyebaran Virus Covid 19 hingga angka 0\% meninggal dunia, ini disebabkan karena Vietnam memberlakukan karantina yang ketat, dan melakukan penelusuran lengkap terhadap semua orang yang berkontak dengan virus ini termasuk penutupan semua sekolah dan universitas selama 14 hari serta Vietnam menutup semua penerbangan. (Pratama, 2020). Selain itu masyarakat Vietnam juga ikut berpartisipasi dalam memerangi virus covid 19 ini dengan mematuhi himbauan yang ditetapkan pemerintah serta kesadaran yang tinggi masyarakat Vietnam.

Belajar dari negara Vietnam maka Indonesia juga memberlakukan hal yang sama, tentunya dengan pertimbangan keadaan social ekonomi masyarakat Indonesia seperti jenis pekerjaan harian lepas, buruh dan lain sebagainya. Oleh sebab itu untuk memberlakukan lockdown seperti di negara Vietnam bukan merupakan hal yang mudah, perlu kesadaran dan partisipasi masyarakat serta ketegasan pemerintah dalam membuat suatu kebijakan. Pemerintah Indonesia telah menghimbau masyarakatnya untuk melakukan physical distancing namun hal ini kurang efektip karena kesadaran dan partisipasi masyarakat dinilai masih rendah terhadap himbauan tersebut.

Berdasarkan hal diatas maka penelitian ini bertujuan untuk mengetahui apakah ada pengaruhnya antara partisipasi masyarakat serta kebijakan yang diterapkan oleh pemerintah dapat mempengaruhi pemutusan mata rantai virus covid 19 .

Menurut Isbandi dalam (Mustanir \& Razak, 2017), partisipasi masyarakat merupakan keterlibatan atau keikutsertaan seseorang masyarakat dalam proses interaksi social, mengindentifikasikan masalah potensi yang ada dimasyarakat dalam situasi tertentu, baik dalam pengambilan keputusan (solusi) menangani masalah, pelaksanaan upaya mengatasi masalah, dan proses keterlibatan masyarakat di dalam mengevaluasi perubahan yang terjadi. Menurut Hasan dalam (Maisur \& Ramzijah, 2019) Terdapat dua faktor yang mempengaruhi partisipasi masyarakat yaitu faktor internal dan eksternal dalam pengurangan penyebaran virus covid 19 yang lebih mendominan adalah faktor internal dimana partisipasi tersebut dipengaruhi oleh karakteristik individu yang mencakup tingkat pendidikan, umur, etnis, pekerjaan, bahasa jumlah pendapatan, dan jumlah beban keluarga. Pemahanan physical distancing melalui work from home (WHF) yang dicanangkan pemerintah tingkat keberhasilannya tergantung kepada faktor internal tersebut.

Menurut Heinz Eulau dan Kenneth Prewitt Kebijakan dapatlah diberi definisi sebagai suatu keputusan yang siap dilaksanakan dengan ciri adanya kemantapan perilaku dan berulangnya tindakan, baik oleh mereka yang membuatnya maupun oleh mereka yang harus mematuhinya. (Soenarko, 2003). Selain itu Chandler dan Plano mendefenisikan kebijakan publik adalah pemanfaatan yang strategis terhadap sumbersumber daya yang ada untuk memecahkan masalah publik atau pemerintah (Pasolong, 2010). Berbagai upaya telah dilakukan oleh pemerintah guna memutus rantai penyebaran virus covid 19 diantarannya melalui himbauan untuk melakukan physical distancing dan work from home kepada masyarakat. Keberhasilan himbauan ini tergantung seberapa tinggi tingkat partisipasi yang ada di masyarakat.

\section{METODE}

Desain penelitian yang digunakan adalah riset kausal yaitu hubungan yang bersifat sebab akibat, dengan metode yang digunakan kuantitatif. Metode ini berlandaskan pada filsafat positivisme dengan memperoleh data yang berbentuk angka atau data kuantitatif yang diangkakan (Sugiyono, 2015). Untuk mengetahui tingkat signifikan dan keterkaitan 
Jurnal Ilmu Sosial dan Pendidikan

Vol. 4. No. 4 November 2020

http://ejournal.mandalanursa.org/index.php/JISIP/index

Terakreditasi Peringkat 5 (No. SK: 85/M/KPT/2020)

antar variabel digunakan metode analisis Structural Equation Modeling (SEM). Instrumen yang digunakan yaitu angket. Survey dilakukan 2 Maret sampai dengan 30 April 2020. Populasi dalam penelitian ini masyarakat di wilayah Jakarta Barat. Sampel dalam penelitian berjumlah 150 orang yang dipilih dengan menggunakan stratified random sampling, sehingga diharapkan dapat mewakili populasi.

\section{HASIL DAN PEMBAHASAN Hasil Penelitian}

Semua pengujian kesesuaian menunjukkan kecocokan yang baik diantaranya: Chi Square (39,71), RMSEA $(0,0049)$, ECVI $(0,63)$, AIC $(93,14)$ dan CAIC $(201,42)$, Fit Index $(>0,90)$, Critical $N$ $(235,23)$ dan Goodness of Fit $(>0,90)$. Dari hasil analisis di atas, dapat disimpulkan bahwa uji kecocokan keseluruh model memenuhi syarat (good fit). Selanjutnya penelitian ini menghasilkan path diagram $\mathrm{T}$-Value sebagai berikut:

Path Diagram T.Value

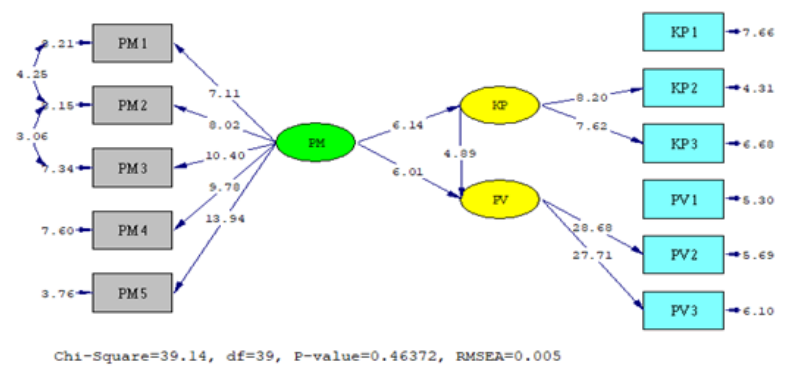

\section{Pengujian Hipotesis}

Pada penelitian ini terdapat tiga hipotesis yang diuji analisis pengujian hipotesis dilakukan dengan tingkat signifikansi 5\% sehingga hipotesis diterima apabila nilai $\mathrm{T}$ value yang di dapatkan $(>1,96)$ sedangkan hipotesis tidak didukung apabila nilai T-value yang di dapatkan $(<1,96)$ (Hair et al., 1998).

Tabel 1 Pengujian Hipotesis Model Penelitian

Jurnal Ilmu Sosial dan Pendidikan

\begin{tabular}{|c|l|c|c|}
\hline Hipotesis & $\begin{array}{l}\text { Pernyataan } \\
\text { Hipotesis }\end{array}$ & T-Value & Keterangan \\
\hline $\mathrm{H}_{1}$ & $\begin{array}{l}\text { Partisipasi } \\
\text { Masyarakat } \\
\text { berpengaruh } \\
\text { terhadap } \\
\text { Kebijakan } \\
\text { Pemerintah }\end{array}$ & 6,14 & $\begin{array}{c}\text { Data } \\
\text { mendukung } \\
\text { hipotesis }\end{array}$ \\
\hline $\mathrm{H}_{2}$ & $\begin{array}{l}\text { Kebijakan } \\
\text { Pemerintah } \\
\text { berpengaruh } \\
\text { terhadap } \\
\text { Penguranan } \\
\text { Penyebaran } \\
\text { Virus Covid } \\
19\end{array}$ & 4,89 & $\begin{array}{c}\text { Data } \\
\text { mendukung } \\
\text { hipotesis }\end{array}$ \\
\hline $\mathrm{H}_{3}$ & $\begin{array}{l}\text { Partisipasi } \\
\text { Masyarakat } \\
\text { berpengaruh } \\
\text { terhadap } \\
\text { Pengurangan } \\
\text { Penyebaran } \\
\text { Virus Covid } \\
19\end{array}$ & 6,01 & $\begin{array}{c}\text { Data } \\
\text { mendukung } \\
\text { hipotesis }\end{array}$ \\
\hline
\end{tabular}

Sumber: Hasil Output SEM Lisrel

\section{PEMBAHASAN HASIL PENELITIAN}

Dari penelitian ini uji hasil hipotesis pertama partisipasi masyarakat berpengaruh terhadap kebijakan pemerintah dengan $t$-value 6,14 , artinya bahwa partisipasi memiliki peranan penting dalam mengambil suatu kebijakan pemerintah khususnya berkaitan dengan penanganan virus covid 19. Partisipasi masyarakat memiliki banyak bentuk, mulai dari yang berupa keikutsertaan langsung masyarakat dalam program pemerintahan maupun yang sifatnya tidak langsung, seperti berupa sumbangan dana, tenaga, pikiran, maupun pendapat dalam pembuatan kebijakan pemerintah, (Lubis, 2009).

Dalam penanganan virus covid 19 terdapat beberapa kebijakan pemerintah yang harus mendapat dukungan oleh masyarakat mulai dari work from home sampai pada pemberlakukan pembatasan social berskala besar (PSBB). Partisipasi yang ada di masyarakat pada situasi virus covid 19 hanya merupakan partisipasi semu yaitu Partisipasi yang didasari oleh sebuah bentuk kesadaran lebih berupaya untuk melakukan perubahan yang mendasar dalam proses kehidupan social (Hikmawati, 2013). 
Terakreditasi Peringkat 5 (No. SK: 85/M/KPT/2020)

Hasil uji hipotesis dua didapat kebijakan pemerintah berpengaruh terhadap pengurangan penyebaran virus covid 19 dengan $t$-value 4,89 , hal ini dinyatakan bahwa dalam pemutus mata rantai virus covid 19 dibutuhkan kebijakan pemerintah yang komprehensip dan sinergi antara pemerintah pusat dengan pemerintah daerah.

Pemeritah pada saat ini sudah melakukan upaya untuk memutus mata rantai penularan virus covid 19 yaitu dengan imbauan untuk menjaga jarak fisik (physical distancing) dengan melakukan kerja dari rumah, belajar di rumah hingga beribadah dirumah. akan tetapi dampak kebijakan tersebut belum berbanding lurus dengan pengurangan kasus virus covid 19. Hal ini disebabkan karena pemerintah hanya menyatakan himbauan terhadap physical distancing tetapi tidak pada pernyataan larangan, sehingga masyarakat masih terindikasi untuk melakukan kontak terhadap penderita covid 19 secara tidak langsung (Lazuardi, 2020).

Selanjutnya uji hipotesis tiga didapatkan partisipasi masyarakat berpengaruh terhadap pengurangan penyebaran virus covid 19 dengan $t$-value 6,01. Hal ini membuktikan bahwa peran serta masyarakat dalam hal ini partisipasi masyarakat memiliki peran penting dalam pengurangan virus covid 19 yaitu secara sukarela mengikuti himbauan pemerintah dengan physical distancing dan work from home. Physical distancing atau pembatasan fisik adalah salah satu cara yang dianjurkan oleh pemerintah untuk memutus mata rantai penyebaran virus covid 19.

Dalam prakteknya Physical distancing dapat dilakukan dengan beberapa cara, diantaranya; (1) jangan keluar rumah kecuali untuk urusan penting, seperti membeli kebutuhan pokok dan obat-obatan, (2) sapa orang lain dengan lambaian tangan, bukan dengan berjabat tangan, (3) bekerja, belajar dan beribadah di rumah, (4) manfaatkan telepon genggam atau video call untuk tetap berhubungan dengan kerabat dan rekan kerja, (5) lakukan olah raga di rumah, tidak di pusat Jurnal Ilmu Sosial dan Pendidikan kebugaran, (6) jika ingin berbelanja kebutuhan sehari-hari, lakukan di luar jam sibuk, (7) minta kurir pengantar barang atau makanan untuk melakukan contactless delivery, dan (8) menunda mengunjungi orang lain atau mudik terutama menjelang Hari Raya Idul Fitri. (Kevin, 2020).

Yang terjadi adalah physical distancing tidak dijalankan dengan baik oleh semua lapisan masyarakat karena beberapa faktor social di masyarakat sehingga menyebabkan penyebaran virus covid 19 terus bertambah diantaranya; (1) masyarakat terlalu percaya diri tidak akan tertural virus corona, (2) masyarakat tidak bepikir secara jernih bahwa dirinya bisa membahayakan diri orang lain, (3) minimnya pengetahuan masyarakat tentang physical distancing, (4) masyarakat tidak berpikir bahwa virus covid 19 tanpa gejala dan penularannya tanpa kita ketahui, dan (5) kurangnya himbauan yang dilakukan pemerintah setempat khususnya camat, lurah, RT dan RW kepada masyarakat terhadap pelaksanaan physical distancing pada lapisan terbawah masyarakat (Novia, 2020). Kelima faktor tersebut harus dijadikan prioritas utama dalam peningkatan kesadaran dan partisipasi masyarakat untuk memerangi virus covid 19 ini.

Salah satu kunci keberhasilan Vietnam dalam memutus mata rantai virus covid 19 adalah dengan meningkatkan partisipasi masyarakatnya yaitu dengan menerapkan retorika perang dan menyatakan bahwa setiap unit usaha, setiap warga negara, setiap area perumahan harus jadi benteng untuk mencegah epidemi. Retorika ini rupanya tepat sasaran karena banyak orang Vietnam bangga dengan kemampuan mereka untuk bahu-membahu menanggung kesulitan selama krisis (Liputan6, 2020).

\section{KESIMPULAN}

Partisipasi masyarakat adalah upaya setiap individu masyarakat untuk mendukung keberhasilan program sesuai dengan 
Jurnal Ilmu Sosial dan Pendidikan

Vol. 4. No. 4 November 2020

http://ejournal.mandalanursa.org/index.php/JISIP/index

Terakreditasi Peringkat 5 (No. SK: 85/M/KPT/2020)

p-ISSN: 2598-9944 e- ISSN: 2656-6753

kemampuan masing-masing orang tanpa mengorbankan kepentingan diri sendiri. Pemutus mata rantai penyebaran virus covid 19 ditentukan oleh partisipasi masyarakat tersebut dengan mendukung sepenuhnya himbauan pemerintah untuk melakukan physical distancing dan work from home secara komprehensif dan menyeluruh. Hasil penelitian ini menunjukkan bahwa dengan kebijakan pemerintah yang sinergis antara pemerintah pusat dan pemerintah daerah serta di dukung oleh partisipasi masyarakat yang tinggi maka penyebaran virus covid 19 dapat berkurang. Penelitian ini dilakukan pada saat pandemic virus covid 19 masih merambak di Indonesia baik di kota besar maupun di kota kecil seperti kabupaten dan desa sehingga secara prosedur penyebaran kuesioner tidak maksimal. Untuk penelitian selanjutnya diharapkan untuk meneliti lebih dalam lagi tentang dampak yang diakibatkan oleh virus covid 19 ini khususnya dampak ekonomi dan dampak keberlangsungan hidup social masyarakat Indonesia.

\section{UCAPAN TERIMA KASIH}

Ucapan terimakasih ditujuhkan kepada Ir. Agus Mulyanto, M.Sc.Ph.D. Ketua Pengurus Harian Yayasan HT, Ir.Azar Hadi Ramli,Ph.D. Ketua STIE MNC., Lutfi Alhazami, SE.,MM. Ketua Program Studi Manajamen STIE MNC., Lu'lu'ul Jannah, SE., M.Si. Kepala LPPM STIE MNC.

\section{DAFTAR PUSTAKA}

DKI Jakarta. (2020). Jakarta Tanggap Covid. https://corona.jakarta.go.id/id

Ferdinand, A. (2006). Metode penelitian manajemen: pedoman penelitian untuk penulisan skripsi. Tesis Dan disertasi Ilmu Managemen, Edisi Dua, Badan Penerbit Universitas ....

Hair, J. F., Anderson, R. E., Tatham, R. L., \& Black, W. C. (1998). Factorial analysis. Multivariate Data Analysis. Fifth Edition. New Jersey: Prentice
Hall.

Hikmawati. (2013). Partisipasi Publik Dalam Perumusan Kebijakan Publik. Jurnal Politik Profetik, 1(1), 1-12.

Indonesia, G. C. 19 R. (2020). Gudus Tugas Percepatan Penanganan Covid 19. https://www.covid19.go.id/situasivirus-corona/

Kevin, A. (2020). Terapkan Physical Distancing Saat Ini Juga. ALODOKTER. https://www.alodokter.com/terapkanphysical-distancing-saat-ini-juga

Lazuardi, G. (2020). Faktor Penyebab Angka Kasus Virus Corona di Indonesia Meningkat Signifikan. TribunNews,Com.

https://www.tribunnews.com/corona/ 2020/03/27/faktor-penyebab-angkakasus-virus-corona-di-indonesiameningkat-signifikan

Liputan6. (2020). Pakai Strategi Perang, Begini Cara Vietnam Menang Lawan Corona Covid 19. https://www.liputan6.com/global/rea d/4212803/pakai-strategi-perangbegini-cara-vietnam-menang-lawancorona-covid-19\#

Lubis, A. (2009). Upaya meningkatkan partisipasi masyarakat dalam pembangunan. Jurnal Tabularasa, 6(2), 181-190.

Maisur, \& Ramzijah. (2019). Pengaruh Partisipasi Masyarakat dan Transparansi Kebijakan Terhadap Pengawasan Dana Desa di Kecamatan Delima, Kabupaten Pidie. Jurnal Sains Riset, 9(3), 1-8. http://journal.unigha.ac.id/index.php/ JSR/article/view/156/151

Mustanir, A., \& Razak, M. R. R. (2017). Nilai Sosial Budaya Pada Partisipasi Masyarakat Etnik Towani Tolotang Dalam Musyawarah Rencana Pembangunan. Prosiding Konferensi Nasional Ke-6 Asosiasi Program Pascasarjana Perguruan Tinggi 
Jurnal Ilmu Sosial dan Pendidikan

Vol. 4. No. 4 November 2020

http://ejournal.mandalanursa.org/index.php/JISIP/index

Terakreditasi Peringkat 5 (No. SK: 85/M/KPT/2020)

Muhammadiyah Aisyiyah (APPPTMA), 1-7.

Novia, A. (2020). 5 Penyebab Physical Distancing Belum Efektif di Masyarakat Indonesia. IDN Times. https://www.idntimes.com/hype/funfact/novia-aisyah/5-penyebabphysical-distancing-belum-efektif-dimasyarakat-indonesia-c1c2-1/5

Pasolong, H. (2010). Teori Administrasi Publik, cetakan kedua. Bandung: Alfabeta, $C V$.

Pratama, F. R. (2020). Vietnam Bebas dari Virus Corona. Kompas.Com. https://www.kompas.com/sports/read /2020/04/25/17200078/vietnambebas-dari-virus-corona-ligavietnam-resmi-bergulir-15mei?page $=$ all

Soenarko. (2003). Pengertin Pokok Untuk Memahami Kebijakan Pemerintah (cetakan 3). Airlangga University Press.

Sugiyono, P. (2015). Metode penelitian kombinasi (mixed methods). Bandung: Alfabeta.

\section{PROFIL PENULIS}

Andi Heru Susanto. S.Sos., M.Si., lahir di Jombang 5 Januari 1975. Penulis menempuh Program S1 di Universitas Krisnadwipaya pada Fakultas Ilmu Administrasi Bisnis pada tahun 1999. Program Pascasarjana (S2) penulis tempuh pada Program Pascasarjana Ilmu Administrasi Publik Universitas Krisnadwipayana tahun 2002. Beberapa judul jurnal telah diterbitkan oleh penulis diantarannya; Pengaruh Kualitas pelayanan Kesehatan terhadap Kepuasan dan Loyalitas (Studi pada Pasien Puskesmas Kelurahan Duri Kepa), Pengaruh Tata Kelola Ruang terhadap Efisiensi Kerja, Peningkatan Sistem Komunikasi dalam Kinerja Pelayanan Publik, dan Pengaruh Partisipasi Masyarakat terhadap Perencanaan, semua judul tersebut diterbitkan oleh Jurnal Ilmu Administrasi (JIA Sandikta). Saat ini penulis tercatat sebagai Dosen Tetap Jurnal Ilmu Sosial dan Pendidikan
Program Studi Manajemen pada Sekolah Tinggi Ilmu Ekonomi Media Nusantara Citra (STIE MNC) 